\title{
Influence of Dietary Change from a Niacin- and Protein-free Diet to a Niacin-free $30 \%$ Casein Diet on Niacin Formation from Tryptophan in Rats ${ }^{\dagger}$
}

\author{
Takashi HayaKawa and Kazuo IwaI* \\ Laboratory of Nutritional Chemistry, Department of Food Science and Technology, \\ Faculty of Agriculture, Kyoto University, Kyoto 606, Japan
}

Received July 2, 1984.

\begin{abstract}
Niacin formation from tryptophan was compared in two groups of rats, one fed a niacin- and protein-free diet (group A) and the other, niacin-free 30\% casein diet (group B) for one day after preliminary feeding of a niacin- and protein-free diet for three days (experiment I). In the other experiment, L-tryptophan was added to the last day's diets (experiment II). NAD and the total niacin contents in liver as well as urinary excretion of pyridine compounds were significantly higher in group I-B than in group I-A. L-Tryptophan supplementation reversed the total niacin content in liver, while total tryptophan intake was about two times higher in group II-B. Since the activities of kynurenine metabolizing enzymes had not changed, we considered that it was not due to a difference in kynurenine metabolism. Urinary excretion of quinolinic acid tended to be higher in group II-A than in group II-B. However, quinolinate phosphoribosyltransferase activity did not differ significantly. On the other hand, the activities of $\alpha$-amino- $\beta$-carboxymuconate- $\varepsilon$ semialdehyde decarboxylase (ACMSDase) in both liver and kidneys were found to be significantly higher in group II-B than in group II-A. This might be responsible for the lower content of liver total niacin in group II-B.
\end{abstract}

Tryptophan has been shown to be a precursor of niacin in many animal species ${ }^{1)}$ including man. ${ }^{2,3)}$ From several nutritional experiments, it is considered that the conversion of tryptophan to niacin is affected by various experimental and physiological conditions in mammals. ${ }^{4 \sim 6)}$ Several factors were known to affect the niacin formation from tryptophan in liver, particularly the related enzyme activities. Thyroxine was reported to reduce NAD formation by lowering the activity of kynurenine 3-hydroxylase (EC 1.14.13.9) and increasing the activity of kynurenine aminotransferase (EC 2.6.1.7). ${ }^{7)}$ Sanada and Miyazaki showed that the activity of $\alpha$-amino- $\beta$-carboxymuconate- $\varepsilon$-semialdehyde decarboxylase (ACMSDase, EC 4.1.1.45) increased in dia- betic rats $^{8)}$ and predonine-injected hypophysectomized rats, ${ }^{9}{ }^{9}$ and that the increase in this enzyme activity by predonine injection was suppressed by bovine somatotropin and mammalian prolactin. ${ }^{9)}$ The levels of dietary protein $^{10)}$ and 5-phosphoribosyl-1-pyrophosphate (PRPP) in liver ${ }^{11)}$ were closely related to the activity of quinolinate phosphoribosyltransferase (QPRTase, EC 2.4.2.19). An increase in NAD glycohydrolase activity (EC 3.2.2.5) was shown to decrease the liver NAD content in fasted rats. ${ }^{12)}$

The above experiments were relatively longterm. In the course of our short-term study, we found that NAD contents in livers of rats fed on a $30 \%$ casein diet for one day followed by a protein-free diet for three days were lower than

$\dagger$ The Biosynthesis of Nicotinamide Adenine Dinucleotide. Part XXI. For Part XX, see ref. 13.

* To whom all correspondence should be addressed.

Abbreviations: QPRTase, quinolinate phosphoribosyltransferase; ACMSDase, $\alpha$-amino- $\beta$-carboxymuconate- $\varepsilon$ semialdehyde decarboxylase; ACMS, $\alpha$-amino- $\beta$-carboxymuconate- $\varepsilon$-semialdehyde; $N$-MNA, $N^{1}$-methylnicotinamide; PRPP, 5-phosphoribosyl-1-pyrophosphate. 
those of the rats fed on a protein-free diet supplemented with tryptophan for one day. ${ }^{13)}$ This study was done to investigate what might be the cause of the different rate of niacin formation from tryptophan between the rats fed a protein-free diet and those fed a $30 \%$ casein diet on the last day, on the basis of tryptophan metabolism including the activities of its metabolizing enzymes.

\section{MATERIALS AND METHODS}

Animals and experimental design. Male rats of the Wistar strain weighing about $150 \mathrm{~g}$ were maintained in a temperature $\left(23^{\circ} \mathrm{C}\right)$ and moisture $(60 \%)$-controlled room with a $12 \mathrm{hr}$ light-dark cycle, and were allowed to free access to drinking water. Diets were fed on the mealfeeding schedule of restricted access to food for $10 \mathrm{hr}$ from 16:00 to 2:00 throughout the experiments. After preliminary feeding of the stock diet for three days, they were individually housed in wire-bottomed stainless cages, and were fed a protein-free diet for three days. The protein-free diet and the other diets used in the following experiments were free from niacin. Then the rats were divided into two groups and were fed the experimental diets for one day. The experimental design and the composition of the protein-free diet are shown in Tables I and II, respectively. The protein-free diet supplemented with L-tryptophan and/or vitamin-free casein at the expense of $\alpha$-cornstarch served as the experimental diet. At 9:30 on the fifth day, all rats were anaesthetized by intraperitoneal injection of $60 \mathrm{mg}$ of pentobarbital $/ \mathrm{kg}$ body weight. One portion of the liver was immediately excised, quickly frozen in liquid nitrogen, and stored at $-20^{\circ} \mathrm{C}$. Kidneys and the other portion of the liver were used for the estimation of the enzyme activities. In experiment II, blood samples were collected by cardiac puncture. Urine samples during the last $24 \mathrm{hr}$ were collected in flasks with $1 \mathrm{ml}$ of $1 \mathrm{~N}$ hydrochloric acid, filled up to $20 \mathrm{ml}$ and kept at $-20^{\circ} \mathrm{C}$ until analysis.

Chemicals. $\left[2,3,7,8-{ }^{14} \mathrm{C}\right] \mathrm{Quinolinic}$ acid was obtained from the Daiichi Pure Chemicals Co., Ltd., Tokyo. Vitamin-free casein and soybean oil were purchased from ICN Pharmaceuticals, Inc., Cleveland, Ohio and Wako Pure Chemical Industries, Ltd., Osaka, respectively. Niacin-free vitamin mixture (type I), $\alpha$-cornstarch, sucrose, mineral mixture (type I), cellulose powder and stock diet (type MF) were obtained from Oriental Yeast Co., Ltd., Tokyo. L-Tryptophan was kindly supplied by Ajinomoto Co., Ltd., Tokyo. 5-Phosphoribosyl-1pyrophosphate (tetrasodium salt, PRPP) was from the Sigma Chemical Co., U. S. A. Other chemicals were of analytical grade and purchased from Nakarai Chemicals, Ltd., Kyoto.
Table I. Composition of Niacin-Free Diets

\begin{tabular}{lcc}
\hline \multicolumn{1}{c}{ Ingredients } & $\begin{array}{c}\text { Protein-free } \\
\text { diet }(\%)\end{array}$ & $\begin{array}{c}30 \% \text { Casein } \\
\text { diet }(\%)\end{array}$ \\
\hline Vitamin-free casein & - & 30 \\
$\begin{array}{l}\alpha \text {-Cornstarch } \\
\text { Sucrose }\end{array}$ & 65 & 35 \\
Soybean oil & 20 & 20 \\
Mineral mixture $^{a}$ & 8 & 8 \\
Cellulose powder $_{\text {Niacin-free vitamin mixture }}^{b}$ & 4 & 4 \\
\hline
\end{tabular}

a One gram of mineral mixture contains (in $\mathrm{mg}$ ): $\mathrm{CaHPO}_{4} 2 \mathrm{H}_{2} \mathrm{O}, 145.6 ; \mathrm{KH}_{2} \mathrm{PO}_{4}, 25.72 ; \mathrm{NaH}_{2} \mathrm{PO}_{4}$, 93.5; NaCl, 4.66, Ca-lactate, 350.9; Fe-citrate, 31.8; $\mathrm{MgSO}_{4}, 71.7 ; \mathrm{ZnCO}_{3}, 1.1 ; \mathrm{MnSO}_{4} 4 \sim 16 \mathrm{H}_{2} \mathrm{O}, 1.2$; $\mathrm{CuSO}_{4} 5 \mathrm{H}_{2} \mathrm{O}, 0.3$ and $\mathrm{KI}, 0.1$.

$b$ One gram of niacin-free vitamin mixture contains: vitamin A acetate, $500 \mathrm{IU}$; vitamin D, $100 \mathrm{IU}$; D- $\alpha$ tocopheryl acetate, $5 \mathrm{mg}$; vitamin $\mathrm{K}_{3}, 5.2 \mathrm{mg}$ thiamin chloride, $1.2 \mathrm{mg}$; riboflavin, $4 \mathrm{mg}$; pyridoxal chloride, $0.8 \mathrm{mg}$; vitamin $\mathrm{B}_{12}, 0.0005 \mathrm{mg}$; ascorbic acid, $30 \mathrm{mg}$; D-biotin, $0.02 \mathrm{mg}$; folic acid, $0.2 \mathrm{mg}$; calcium panthothenate, $5 \mathrm{mg}$; $p$-aminobenzoic acid, $5 \mathrm{mg}$; inositol, $6 \mathrm{mg}$ and choline chloride, $200 \mathrm{mg}$.

Determination of $N A D$, its related compounds, and tryptophan metabolites. Just before analysis, the frozen livers were powdered with a pestle and a mortar which had been chilled at $-20^{\circ} \mathrm{C}$ and served as the samples for the determination of the total niacin and NAD. Extraction and determination of NAD were performed by the method reported by Nisselbaum and Green. ${ }^{14)}$ The total niacin content in liver and blood were determined microbiologically using Lactobacillus arabinosus (ATCC 8014) as the test organism. ${ }^{15)}$ Xanthurenic acid was determined fluorometrically as described by Satoh and Price. ${ }^{16)}$ The quinolinic acid content in the urine was evaluated as the difference between the value of the total niacin content obtained by microbioassay of untreated urine as described above and that of the urine treated by autoclaving at $120^{\circ} \mathrm{C}$ for two hr with the same volume of glacial acetic acid. ${ }^{17)} N^{1}$-Methylnicotinamide ( $N$-MNA) was measured by the method of Nose and Ueda. ${ }^{18)}$ Creatinine was determined according to the alkaline picrate method of Peters. ${ }^{19)}$

Estimation of the enzyme activities. Fresh liver and kidneys were finely minced, mixed with eight volumes of $0.25 \mathrm{M}$ sucrose, and homogenized using a Potter-Teflon homogenizer. Then the volume was adjusted to ten times the volume of the weight of the organ used. Subcellular components were obtained by the method of De Duve et $a l .{ }^{20)}$ An ultracentrifugal supernatant was obtained after centrifugation of the postmitochondrial supernatant at $105,000 \times g$ for $30 \mathrm{~min}$. Kynurenine 3-hydroxylase activity 
Table II. Experimental Design and Food and Tryptophan Intakes on the Last Day

\begin{tabular}{|c|c|c|c|c|c|}
\hline \multirow{2}{*}{ Experiment } & \multirow{2}{*}{ Group } & \multicolumn{2}{|c|}{ Feeding conditions } & \multirow{2}{*}{$\begin{array}{c}\text { Food intake } \\
(\mathrm{g})\end{array}$} & \multirow{2}{*}{$\begin{array}{l}\text { Total Trp } \\
\text { intake } \\
\quad(\mu \mathrm{mol})\end{array}$} \\
\hline & & $\begin{array}{l}\text { Diet for the } \\
1 \text { st } \sim 3 \text { rd day }\end{array}$ & $\begin{array}{l}\text { Diet for the } \\
4 \text { th day }\end{array}$ & & \\
\hline \multirow[t]{2}{*}{ I } & $\mathrm{I}-\mathrm{A}(5)^{*}$ & Protein-free diet & Protein-free diet & $13.47 \pm 0.64^{* *}$ & 0 \\
\hline & $\mathrm{I}-\mathrm{B}(5)$ & Protein-free diet & $30 \%$ Casein diet & $13.88 \pm 0.04$ & $267 \pm 1$ \\
\hline \multirow[t]{2}{*}{ II } & $\mathrm{II}-\mathrm{A}(5)$ & Protein-free diet & $\begin{array}{l}0.39 \% \text { Trp-supplemented } \\
\text { protein-free diet }\end{array}$ & $9.40 \pm 0.57$ & $179 \pm 11$ \\
\hline & $\mathrm{II}-\mathrm{B}(5)$ & Protein-free diet & $\begin{array}{l}0.39 \% \text { Trp-supplemented } \\
30 \% \text { casein diet }\end{array}$ & $9.82 \pm 0.13$ & $368 \pm 6$ \\
\hline
\end{tabular}

* Number of rats in parentheses.

** Values are means \pm S.D.

Table III. NAD Content in the Liver and the Total Niacin Contents in the LIVER AND THE BLOOD

\begin{tabular}{lccccc}
\hline & \multicolumn{2}{c}{ Experiment I } & & \multicolumn{2}{c}{ Experiment II } \\
\cline { 2 - 3 } \cline { 5 - 6 } & Group I-A & Group I-B & & Group II-A & Group II-B \\
\hline NAD & & & & \\
$\quad \mu$ mol/g liver & $0.233 \pm 0.018^{* a^{* * *}}$ & $0.336 \pm 0.037^{a}$ & & $0.795 \pm 0.155$ & $0.724 \pm 0.050$ \\
$\quad \mu \mathrm{mol} /$ liver & $1.51 \pm 0.18^{b}$ & $2.67 \pm 0.31^{b}$ & & $4.79 \pm 0.87$ & $4.80 \pm 0.17$ \\
$\begin{array}{l}\text { Total niacin } \\
\mu \mathrm{mol} / \mathrm{g} \text { liver }\end{array}$ & $1.08 \pm 0.08$ & $1.15 \pm 0.12$ & & $1.82 \pm 0.19^{d}$ & $1.35 \pm 0.13^{d}$ \\
$\mu \mathrm{mol} /$ liver & $7.01 \pm 0.26^{c}$ & $9.06 \pm 1.16^{c}$ & & $11.36 \pm 0.65^{e}$ & $8.93 \pm 0.53^{e}$ \\
$\mu \mathrm{mol} / \mathrm{ml}$ blood & $0.121 \pm 0.005$ & $0.111 \pm 0.013$ & & $0.141 \pm 0.013^{f}$ & $0.098 \pm 0.007^{f}$ \\
\hline
\end{tabular}

* Values are means \pm S.D.

** Common superscript letters mean significant difference at $p<0.05$.

was measured by a modification of the method of Linzen $^{21)}$ and Mayer and Staudinger ${ }^{22)}$ as described by Schott et al. ${ }^{23)}$ Kynurenine aminotransferase was measured by the increase in absorbance at $330 \mathrm{~nm}$ originating from kynurenic acid formation. ${ }^{24)}$

Kynurenine hydrolase activity was assayed by measuring anthranilate fluorometrically. ${ }^{25)}$ ACMSDase activity was measured by the method of Ichiyama et al. ${ }^{26)}$ QPRTase activity was assayed according to the method described by Iwai and Taguchi. ${ }^{27)}$

\section{RESULTS}

\section{Food and L-tryptophan intakes}

In this kind of experiment, food intake is important because the amounts of NAD and related compounds in rat liver and tryptophan metabolites in the urine depends on it. Therefore, considerable attention has been paid to the food intake by rats. As shown in Table II, there was no significant difference in food intake between the groups on the last day in experiments I and II. In experiment II, free L-tryptophan intake also did not differ significantly $(179 \pm 11 \mu \mathrm{mol}$ Trp/rat for group II-A and $188 \pm 2 \mu \mathrm{mol} \mathrm{Trp} /$ rat for group II-B). Considering the L-tryptophan content in casein was about $1.3 \%$, the intakes of $\mathrm{L}$ tryptophan were $267 \pm 1 \mu \mathrm{mol}$ and $181 \pm$ $4 \mu \mathrm{mol}$ in groups I-B and II-B, respectively (Table II). Thus, total L-tryptophan intake in group II-B reached $368 \pm 6 \mu$ mol.

\section{$N A D$ content in the liver and the total niacin} contents in the liver and the blood

Pyridine nucleotide status in liver was expressed as NAD and the total niacin contents. As shown in Table III, the NAD content was statistically higher in group I-B than in group I-A in both $\mu \mathrm{mol} / \mathrm{g}$ wet liver and $\mu \mathrm{mol} /$ liver. 
Table IV. Urinary Excretion of Creatinine, Xanthurenic Acid, Quinolinic Acid, Niacin, AND $N$-MNA IN EXPERIMENTS I AND II ON THE LAST DAY

\begin{tabular}{|c|c|c|c|c|}
\hline & \multicolumn{2}{|c|}{ Experiment I } & \multicolumn{2}{|c|}{ Experiment II } \\
\hline & Group I-A & Group I-B & Group II-A & Group II-B \\
\hline \multicolumn{5}{|l|}{ Creatinine } \\
\hline $\begin{array}{l}\text { Xanthurenic acid } \\
\mu \mathrm{mol} / \mathrm{mg} \text { creatinine }\end{array}$ & $0.113 \pm 0.028^{a * *}$ & $0.164 \pm 0.008^{a}$ & $10.7 \pm 3.5$ & $12.6 \pm 4.0$ \\
\hline $\begin{array}{l}\text { Quinolinic acid } \\
\mu \mathrm{mol} / \mathrm{mg} \text { creatinine } \\
\text { Niacin }\end{array}$ & $0.034 \pm 0.006^{b}$ & $0.221 \pm 0.038^{b}$ & $2.43 \pm 1.45$ & $1.17 \pm 0.45$ \\
\hline $\begin{array}{l}\mu \mathrm{mol} / \mathrm{mg} \text { creatinine } \\
N \text {-MNA }\end{array}$ & $0.038 \pm 0.008^{c}$ & $0.082 \pm 0.004^{c}$ & $0.283 \pm 0.113$ & $0.426 \pm 0.268$ \\
\hline$\mu \mathrm{mol} / \mathrm{mg}$ creatinine & $0.130 \pm 0.022^{d}$ & $0.347 \pm 0.071^{d}$ & $1.04 \pm 0.73$ & $0.98 \pm 0.61$ \\
\hline \multicolumn{5}{|c|}{$\begin{array}{l}* \quad \text { Values are means } \pm \text { S.D. } \\
* * \quad \text { Common superscript letters mean significant difference at } p<0.05 \text {. }\end{array}$} \\
\hline & \multicolumn{2}{|c|}{ Liver } & \multicolumn{2}{|c|}{ Kidney } \\
\hline & Group II-A & Group II-B & Group II-A & Group II-B \\
\hline & \multicolumn{2}{|c|}{$\mu \mathrm{mol} / \mathrm{hr} / \mathrm{g}$ tissue } & \multicolumn{2}{|c|}{$\mu \mathrm{mol} / \mathrm{hr} / \mathrm{g}$ tissue } \\
\hline $\begin{array}{l}\text { Kynurenine } \\
\text { 3-hydroxylase }\end{array}$ & $1.86 \pm 0.27$ & $2.19 \pm 0.44$ & $2.51 \pm 0.21$ & $2.75 \pm 0.11$ \\
\hline $\begin{array}{l}\text { Kynurenine } \\
\text { aminotransferase }\end{array}$ & $1.07 \pm 0.16$ & $1.00 \pm 0.23$ & $5.58 \pm 0.48$ & $6.17 \pm 0.62$ \\
\hline $\begin{array}{l}\text { Kynurenine } \\
\text { hydrolase }\end{array}$ & $1.77 \pm 0.32$ & $1.90 \pm 0.19$ & $0.27 \pm 0.04$ & $0.28 \pm 0.02$ \\
\hline ACMSDase & $1.41 \pm 0.30^{a * *}$ & $2.44 \pm 0.62^{a}$ & $23.7 \pm 2.5^{b}$ & $31.8 \pm 2.6^{b}$ \\
\hline QPRTase & $0.23 \pm 0.03$ & $0.23 \pm 0.07$ & - & - \\
\hline
\end{tabular}

When expressed as $\mu \mathrm{mol} /$ liver, the total niacin content in group II-B was also statistically higher than that in group II-A, although its values expressed as $\mu \mathrm{mol}$ niacin/g wet liver gave no significant difference. In experiment II, NAD content was not significantly different, but the total niacin content in group IIA became significantly higher than that in group II-B. In blood, the total niacin content was slightly higher in group I-A than in group I-B, though it was not significantly different. However, group II-A had a significantly higher content of blood total niacin than group II-B.
Effects of dietary change on the urinary excretion of creatinine, xanthurenic acid, quinolinic acid, niacin, and $N-M N A$

Urinary excretion of creatinine on the last day was almost the same between the two groups in experiments I or II. The results of Table IV showed that group I-B excreted more xanthurenic acid, quinolinic acid, niacin, and $N$-MNA than group I-A did. However, no significant difference in the urinary excretion of these compounds was observed when Ltryptophan was provided to these two groups as in experiment II. From these results, Ltryptophan supplementation exerted more effect on the urinary excretion of pyridine com- 
pounds in group II-A than in group II-B.

Effects of dietary change on the activities of some enzymes involved in tryptophan metabolism

Quinolinic acid formation from tryptophan has been shown to have two channellings on its pathway, namely kynurenine channelling at mitochondria and $\alpha$-amino- $\beta$-carboxymuconate- $\varepsilon$-semialdehyde (ACMS) channelling in cytoplasma by ACMSDase. ${ }^{7,26)}$ In experiment II, the casein diet on the last day had no influence on the activities of the three enzymes concerned in kynurenine metabolism, i.e. kynurenine 3-hydroxylase, kynurenine aminotransferase, and kynurenine hydrolase. The activity of QPRTase, which catalyzed the formation of the first niacin-active compound, nicotinic acid mononucleotide, from quinolinic acid and PRPP, also did not differ statistically (Table V). In contrast, ACMSDase activity increased significantly in both liver and kidneys. In experiment I, ACMSDase activity in liver was also higher in group I-B than in group I-A (in $\mu \mathrm{mol} / \mathrm{hr} / \mathrm{g}$ liver: group I-A, $0.662 \pm 0.063$; group I-B, $1.655 \pm 0.467 ; p<$ $0.05)$.

\section{DISCUSSION}

L-Tryptophan was added to the last-day's diets for the rats which were fed a protein-free diet for three days, and its effects on the levels of pyridine compounds in both liver and urine was examined (experiment II) in comparison with experiment I. NAD and the total niacin contents in liver were significantly higher in group I-B than in group I-A. The increased contents of liver NAD and the total niacin in group I-B compared to those in group I-A would be due to the conversion of $\mathrm{L}$ tryptophan to niacin. This was confirmed by the increased urinary excretion of tryptophan metabolites in group I-A as shown in Table IV. On the other hand, the total niacin content in group II-A became significantly higher than that in group II-B, whereas total L-tryptophan intake was about two times higher in group II-
B than in group II-A. These results were in conflict with the usual manner of niacin formation, in which the amount of liver total niacin was dependent on the amounts of its precursors injested. Since changes in the activities of kynurenine 3-hydroxylase and kynurenine aminotransferase by thyroxine were reported to be involved in the reduced NAD $(\mathrm{P})$ content in rat liver, ${ }^{7)}$ and since niacin formation from tryptophan was mainly affected by ACMSDase activity, ${ }^{26}$ ) we examined the activities of these enzymes and others involved in the niacin formation from tryptophan in experiment II. As shown in Tables IV and V, no significant difference was observed between group II-A and II-B in the activities of kynurenine 3-hydroxylase, kynurenine aminotransferase, kynurenine hydrolase, and QPRTase, or in the urinary excretion of tryptophan metabolites. ACMSDase activity, however, increased significantly in both liver and kidneys. Thus, we assumed that the lower content of the liver total niacin in group II-B would be due to a decrease in the quinolinic acid formation by increasing the activity of ACMSDase, as compared to group II-A.

Chaloupka et $a .^{28)}$ reported that $\mathrm{L}$ tryptophan provided to rats depleted of blood pyridine nucleotides by a niacin-tryptophandeficient diet was used for nitrogen equilibrium, growth, and synthesis of blood pyridine nucleotides in this order, according to the increase in the amount of L-tryptophan provided. In their experiments, tryptophan was a limiting amino acid. However, it was not a limiting amino acid in our experiments using casein as a source of protein. So the $30 \%$ casein diet after a protein-free diet increased the total niacin content in liver as shown in experiment I-B. Yoshida ${ }^{29)}$ presented the hypothesis from an amino acid supplementation study with a rice diet lacking niacin that the addition of all limiting amino acids other than L-tryptophan would increase the use of Ltryptophan for protein synthesis and might lead to niacin deficiency. These results stood on the viewpoint of amino acid imbalance under which tryptophan utilization for NAD 
biosynthesis was limited, and also they did not refer to the pyridine nucleotide status in the liver. Our results were not fully explained by the concept of amino acid imbalance. In our experiments, enough tryptophan was present and would be metabolized in a similar manner up to ACMS in both groups II-A and II-B, since xanthurenic acid in urine was almost the same. Thus the lower content of the liver total niacin in group II-B would mainly result from a decrease in the quinolic acid formation by increasing the ACMSDase activity, but not tryptophan deficiency by amino acid imbalance. The responce of ACMSDase activity to a $30 \%$ casein diet was relatively rapid and was thought to be important for the short-term regulation of niacin formation from tryptophan in vivo. Recently, Sanada and Miyazaki $^{30)}$ reported that a high-protein diet elevated ACMSDase activity in liver and kidneys of rat. Their report is not inconsistent with our present results. However, it was uncertain what mechanism was involved in the enhancement of ACMSDase activity in our short-term study. Further investigation is now in progress.

Acknowledgments. The authors wish to thank Dr. Katsumi Shibata, Faculty of Domestic Science, Teikoku Women's University, Moriguchi, Osaka, and Dr. Tohru Fushiki, Department of Food Science and Technology, Kyoto University, for their kind discussion and suggestions.

\section{REFERENCES}

1) W. A. Perlzweig, F. Rosen and P. B. Pearson, $J$. Nutr., 40, 453 (1950).

2) W. A. Perlzweig, F. Rosen, N. Levitas and J. Robinson, J. Biol. Chem., 167, 511 (1947).

3) H. P. Sarett and G. A. Goldsmith, J. Biol. Chem., 167, 293 (1947).

4) G. A. Goldsmith, O. N. Miller and W. G. Unglaub, J. Nutr., 73, 172 (1961).

5) I. Nakagawa, T. Takahashi, T. Suzuki and Y.
Masana, J. Nutr., 99, 325 (1969).

6) C. F. Consolazio, H. L. Johnson, H. J. Krzywicki and N. F. Witt, Am. J. Clin. Nutr., 25, 572 (1972).

7) H. Okamoto, F. Okada and O. Hayaishi, J. Biol. Chem., 246, 7759 (1971).

8) H. Sanada, M. Miyazaki and T. Takahashi, J. Nutr. Sci. Vitaminol., 246, 449 (1980).

9) H. Sanada and M. Miyazaki, J. Nutr. Sci. Vitaminol., 26, 607 (1980).

10) U. Satyanarayana and B. S. Narasinga Rao, Br. J. Nutr., 38, 39 (1977).

11) K. Shibata and K. Iwai, Agric. Biol. Chem., 44, 2785 (1980).

12) M. Shimoyama, M. Ohota, K. Kakehi and I. Ueda, Biochim. Biophys. Acta, 215, 207 (1970).

13) T. Hayakawa and K. Iwai, J. Nutr. Sci. Vitaminol., 30, 303 (1984).

14) J. S. Nisselbaum and S. Green, Anal. Biochem., 27, 212 (1969).

15) K. Iwai, O. Okinaka and H. Yokomizo, Vitamins (in Japanese), 35, 387 (1967).

16) K. Satoh and J. M. Price, J. Biol. Chem., 230, 781 (1958).

17) L. M. Henderson, J. Biol. Chem., 181, 677 (1949).

18) Y. Nose and K. Ueda, Vitamins (in Japanese), 2, 247 (1949).

19) J. H. Peters, J. Biol. Chem., 146, 179 (1942).

20) C. De Duve, B. C. Pressman, R. Gianetto, R. Wattiaux and F. Appelmans, Biochem. J., 60, 604 (1955).

21) B. Linzen, Hoppe-Seyler's Z. Physiol. Chem., 333, 145 (1963).

22) V. G. Mayer and H. Staudinger, Hoppe-Seyler's Z. Physiol. Chem., 348, 733 (1967).

23) H. Schott, V. Ullrich and H. Staudinger, HoppeSeyler's Z. Physiol. Chem., 351, 99 (1970).

24) M. Mason, J. Biol. Chem., 211, 839 (1954).

25) S. C. Schlitt, G. Lester and P. J. Russel, J. Bacteriol., 117, 1117 (1974).

26) A. Ichiyama, S. Nakamura, H. Kawai, T. Honjo, Y. Nishizuka, O. Hayaishi and S. Senoh, J. Biol. Chem., 240, 740 (1965).

27) K. Iwai and H. Taguchi, J. Nutr. Sci. Vitaminol., 19, 491 (1973).

28) M. M. Chaloupka, J. N. Williams Jr., M. S. Reynolds and C. A. Elvehjem, J. Nutr., 63, 361 (1957)

29) A. Yoshida, Agric. Biol. Chem., 35, 1943 (1971).

30) H. Sanada and M. Miyazaki, J. Nutr. Sci. Vitaminol., 30, 113 (1984). 